\title{
The Correlation of Safe Nursing Care with the Quality of Work Life of
}

\section{Nurses}

\author{
Masoumeh Fotoohi ${ }^{1}$, Ezzat Jafar Jalal ${ }^{2}$, Hamid Haghani ${ }^{3}$
}

\begin{abstract}
Background \& Aims: One of the primary goals of health service provision is to prevent patient harm and maintain patient safety. Patient safety is defined as minimizing the risk of unnecessary injuries compared to other treatments or lack of treatment. Safe nursing care has four dimensions of nursing skills, providing physical safety, providing mental safety, and nurses' cooperation with other members. The provision of safe care depends on the quality and efficiency of nursing services. The efficiency of nurses depends on the measures taken to preserve the body and mind of nurses and the improvement of the quality of their work life. Quality of work life emphasizes personal consequences and professional improvement to meet one's needs in the four dimensions of personal life, work framework, work context, and global dimension of work. Safe care and quality of work life are important issues, and their dimensions have been assessed and identified separately in some studies, while they could be fully recognized and promoted through more approaches. The present study aimed to assess the correlation of safe nursing care and the quality of work life of nurses in the public hospitals of Rasht, Iran in 2020.

Materials \& Methods: This cross-sectional, descriptive-correlational study was conducted to assess the correlation between safe nursing care and quality of work life in eight public hospitals in Rasht. The participants included 250 nurses who were selected via stratified sampling based on the ratio of the total number of the nurses in the public hospitals of Rasht and each hospital department accessibly. Data were collected using a demographic questionnaire, Brooks' quality of work life (QWL) for nurses (2005), and Rashvand safe nursing care questionnaire (2017). Brooks' QWL questionnaire has four dimensions regarding the quality of work life of nurses with 42 items, including personal life (seven items), work framework (10 items), work field (20 items), global work dimension (five items). Each items was assigned a score within the range of 1-6 (Strongly Disagree=1, Strongly Agree=6) within the score range of 42-252. The reliability coefficient of this questionnaire has been confirmed at the Cronbach's alpha of 0.91. Rashvand safe nursing care questionnaire had 33 items in the four dimensions of nursing skills (16 items), mental safety (four items), physical safety (seven items), team work (five items), and one general question. The demographic and QWL questionnaires were completed by the nurses, and the safe nursing care questionnaire was completed by the nursing supervisor. Sampling was performed during September 22-October 20, 2020, and each questionnaire was completed within 20-30 minutes. The inclusion criterion was employment in a public hospital in Rasht, and the exclusion criteria were incomplete questionnaires and not returning the questionnaires. After the sampling process, 250 questionnaires were collected. Data analysis was performed in SPSS version 16 using descriptive statistics (absolute and relative frequency, mean, and standard deviation) and inferential statistics (independent t-test, analysis of variance, and Pearson's correlation-coefficient), and the significance level was considered $<0.05$.
\end{abstract}

Results: The quality of work life of the majority of the nurses $(78.8 \%)$ was moderate. The highest and lowest mean scores were obtained in the work field dimension $(58.37 \pm 15.74)$ and the global work dimension $(41.92 \pm$ $18)$, respectively. In the majority of the studied nurses $(94.4 \%)$, the level of safe nursing care was favorable and

\footnotetext{
1. Master of Nursing Management, School of Nursing and Midwifery, Iran University of Medical Sciences, Tehran, Iran

2. Department of Nursing Management, School of Nursing and Midwifery, Iran University of Medical Sciences, Tehran, Iran (Corresponding author) Tel: $42401000 \quad$ Email: Jafarjalal.e@iums.ac.ir 3 . Department of Biostatistics, School of Health, Iran University of Medical Sciences, Tehran, Iran
} 
higher, while their cooperation level with the other healthcare team members was lower comparatively. Safe nursing care had no significant correlation with the quality of work life and none of its dimensions. In addition, none of the demographic variables were significantly correlated with the quality of work life of the studied nurses. However, safe nursing care had significant correlations with gender, marital status, employment status, age, and work experience $(\mathrm{P}>0.001)$.

Conclusion: Despite the moderate quality of work life, safe nursing care was considered favorable. However, no significant correlations were observed between safe nursing care, the quality of working life, and its dimensions. This finding could be due to the prevailing professional rules and beliefs in the nursing profession, which maintains safe care despite the limitations in the factors associated with the quality of work life. Although safe nursing care was favorable, the constantly increasing need for promoting the quality of care and the competition of care service organizations to attract more clients, safe nursing care must be enhanced continuously. According to the findings, the dimension of clinical skills was rather poor in terms of safe nursing care, which requires skills retraining and further monitoring in this regard. Since the global quality of work life mainly concerns nurses, chief executives must pay special attention to the salaries and wages of these individuals, as well as their job security and presenting a correct image of nursing to the society.

Keywords: Quality of Work Life, Nurse, Safe Nursing Care, Safe Performance of Nurses

\section{Conflict of Interest: No}

How to Cite: Fotoohi M, Jafar Jalal E, Haghani H. The Correlation of Safe Nursing Care with the Quality of Work Life of Nurses. Iran Journal of Nursing. 2021; 33(128):1-14.

Received: 2 Nov 2020

Accepted: 1 Feb 2021 


\title{
ارتباط مر اقبت يرستارى ايمن با كيفيت زندكى كارى برستاران
}

\author{
معصومه فتوحى '، عزت جعفر جلال '، حميد حقانى
}

جكيده

زمينه و هدف: يبشخيرى از آسيب به بيمار، ابتدايى ترين هدف در ارائهى خدمات بهداشتى - درمانى است. مراقبت ايمن و كيفيت زندكى كارى، موضوعات

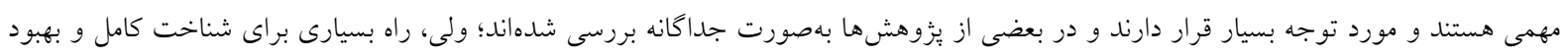

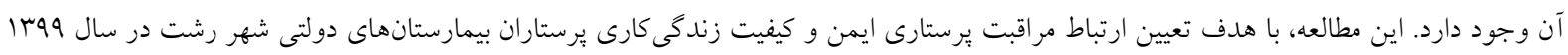
انجام شد. روش بررسى: اين يزوهش، بهصورت مقطعى، از نوع توصيفى - همبستحى انجام شد و ارتباط بين دو متغيّر مراقبت يرستارى ايمن و كيفيت زندكى كارى

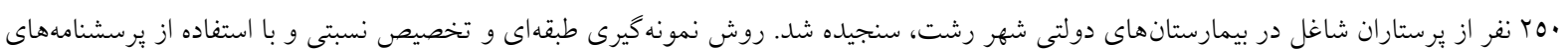

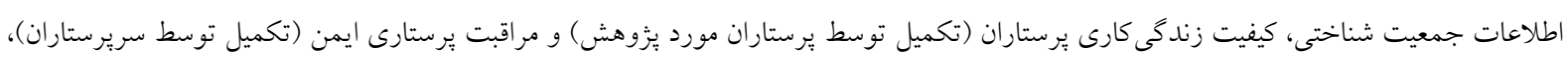

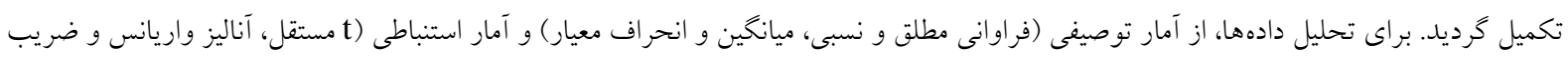

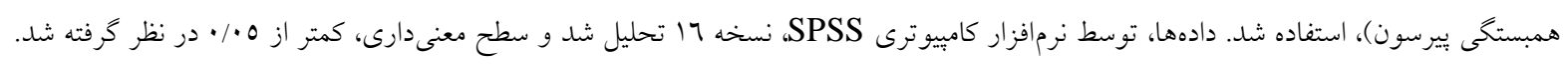

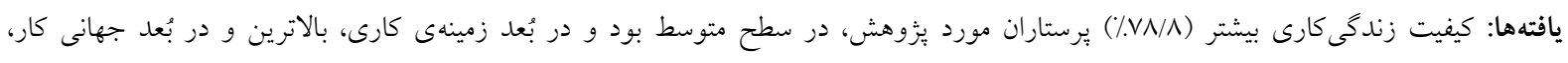

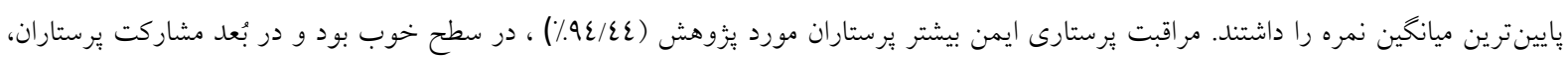

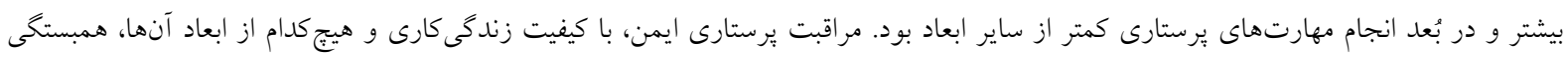

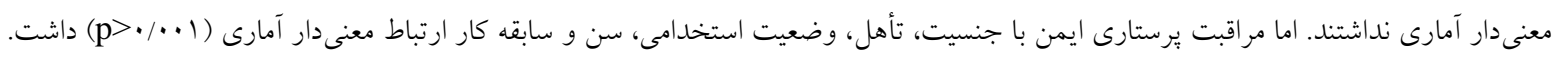

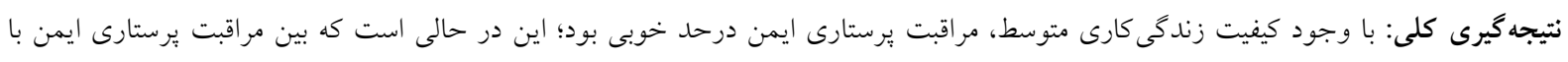

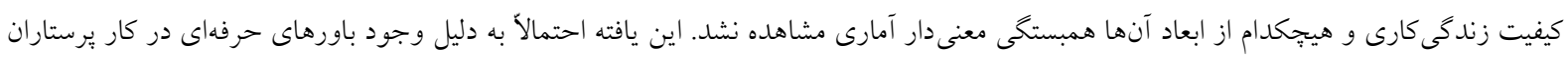
است كه باعث شده با وجود كاستى هاى موجود در عو امل مربوط به كيفيت زندكى كارى، مراقبت ارائه شده همجنان كاملاً ايمن باشد.

كليد وازهها: كيفيت زندگى كارى، يرستار، مراقبت برستارى ايمن، عملكرد ايمن برستار

تعارض منافع: ندارد

تاريخ دريافت: T9/N/IT

تاريخ يذيرش:

' ' كارشناس ارشد مديريت يرستارى، دانشكده يرستارى مامايى، دانشخاه علوم يزشكى ايران، تهران، ايران

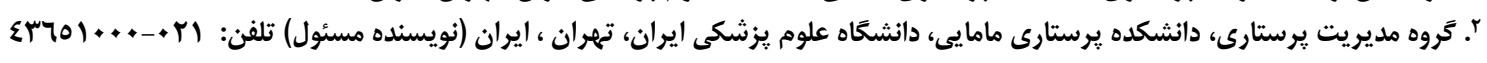
". تَروه آمار زيستى، دانشكده بهداشت، دانشًَاه علوم يزشكى ايران، تهران، ايران 
سيستم سلامت و افراد جامعه مى گردد و بار اقتصادى عظيمى را بر سيستم بهداشتى درمانى و جامعه تحميل

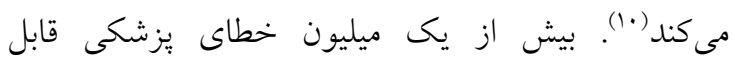

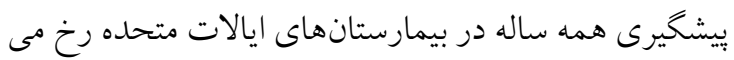

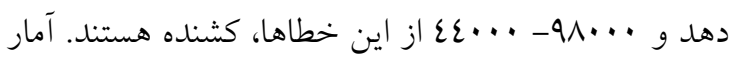
بالاى خطاهاى يزشكى در مطالعات مختلف، اين خطاها را

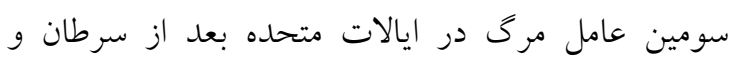

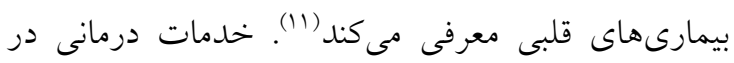
محيطى ظر از عوامل متعدد و يِيجيده، شامل خود بيمار، مراقبان و اعضاى خانواده، تجهيزات، سياست مديران، رويهها و منابع به بيمار عرضه مى گرددد. زمانى كه اين

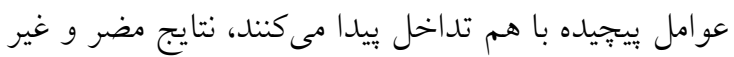
قابل بيش بينى به وجود مى آيد (ז'). اخرجه يرستاران بهعنوان بزرگترين گروه مراقبتى، وظيفه

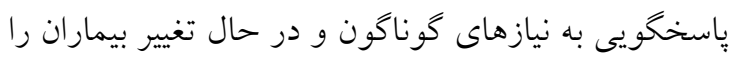

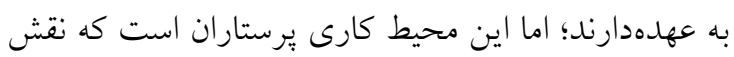

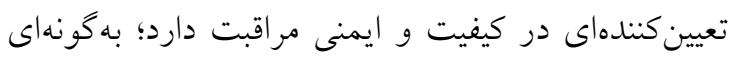

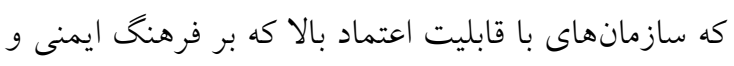

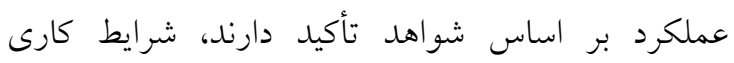

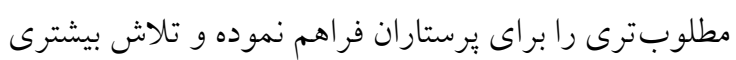

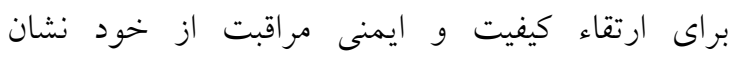

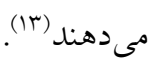
امروزه، جֶنان زندگى خصوصى انسان درهم تنيده شده كه

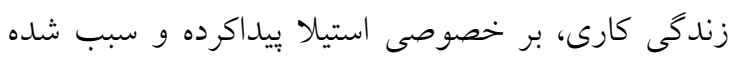

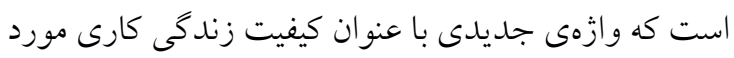

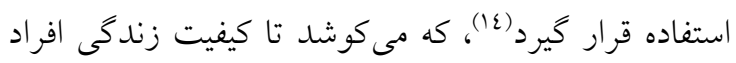
شاغل را بهبود بخشد و سعى مى كند به نيازهاى شغلى كه فئ به نقش يكى عامل توليد در كنار ديخر عوامل توليد، مانند

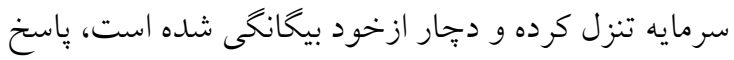

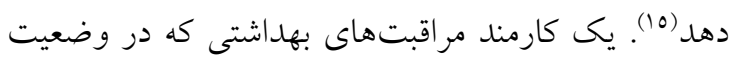
خستخى به سر مىبرد، خطرى براى سلامت عمومى و

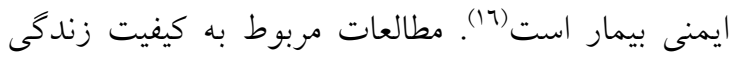
كارى، از دهه •190 آغاز شد. ضرورت توجه به كيفيت آنمان

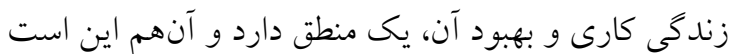

\section{مقدمه}

هر جامعهاى براى يويايى و ييشرفت نياز به شهروندانى

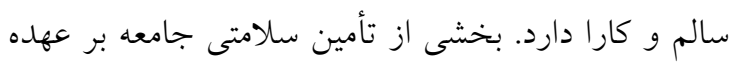

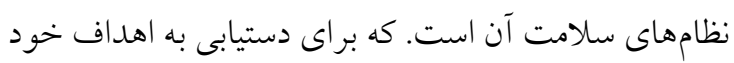

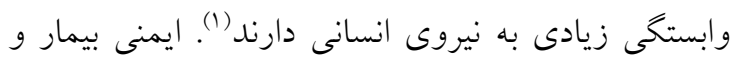
كيفيت در قلب ارايه مراقبت سلامتى هستند و فراهم كردن رئن

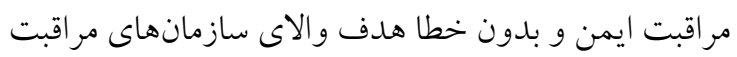

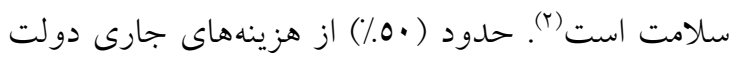
در بخش بهداشت و درمان به بيمارستانها تعلق مى گيرد و "يرستاران نيز بزرگترين عضو نظام سلامت كشور هستند و نقش اساسى در تداوم مراقبت، ارتقاو حفظ سلامت در سطوح مختلف سيستم ارايه خدمات سلامت را ايفا

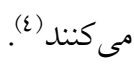
رعايت ايمنى بيمار از اجزاى مهم كيفيت مراقبت در نظام

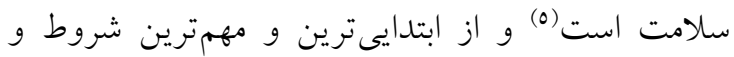

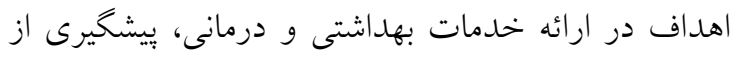
آسيب به بيمار و به مخاطره انداختن ايمنى او درنتيجه ارائه ى خدمات سلامت است(1). تأكيد بر حفظ ايمنى بيماران،

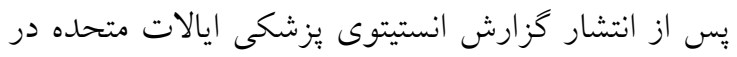

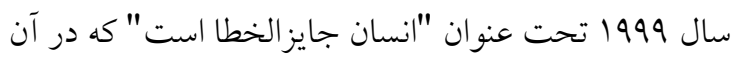
به بررسى ميزان شيوع خطاهاى بزشكى در اين كشور

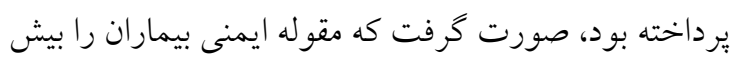

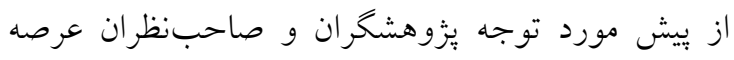

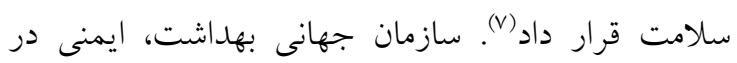
محيط ارائهى خدمات سلامتى و درمانى را (اكاهش احتمال

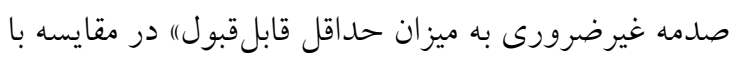
ساير روشهاى درمان و يا عدم اقدام به درمان مىداند (^).

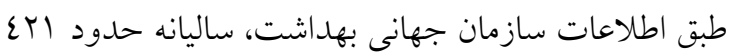
ميليون بسترى در بيمارستانهاى جهان اتفاق مىافتل و

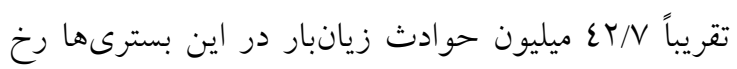

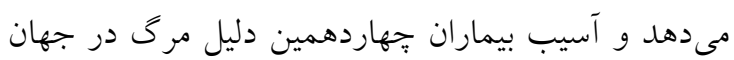

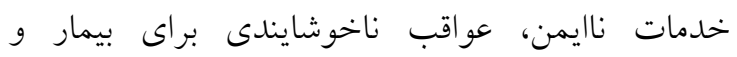
خانو ادهى او دارد و باعث وارد آمدن فشار روانى بر كاركنان 
خانواده، اوقات فراغت و نيازهاى اجتماعى آنان را نيز

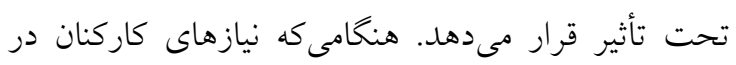

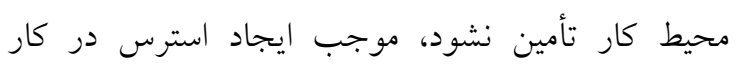
مىشود كه نتايج و عواقب نامناسبى در رفاه و عملكرد

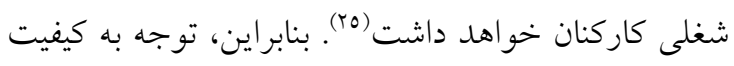

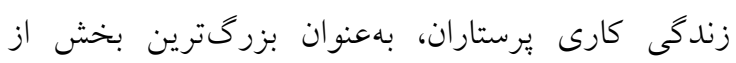

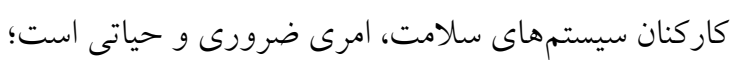

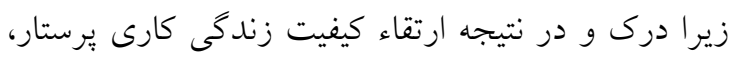

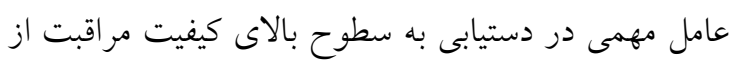

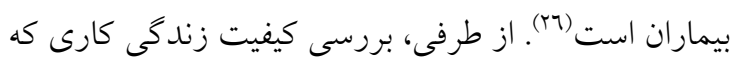

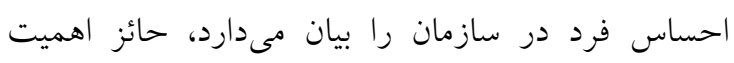

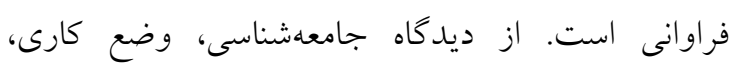

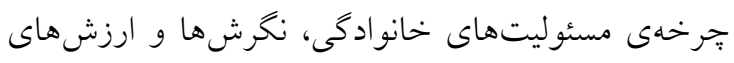

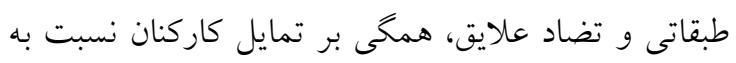
كار و نغرش او نسبت به شغلش اثر مى خذارد. كاركنان

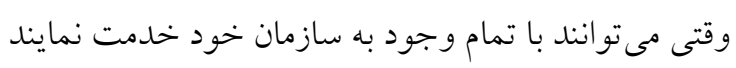
كه نيازهاى شخصى و خانوادكى آنان بهطور نسبى ارضاء

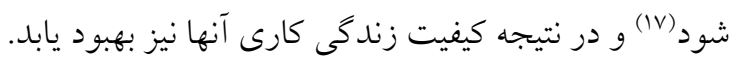
با توجه به اهميتى كه كيفيت زندگى كارى برستار ان دارد و

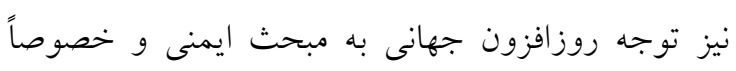
مراقبتهاى ايمن، و در عين حال كاستى هاى موجود كه در

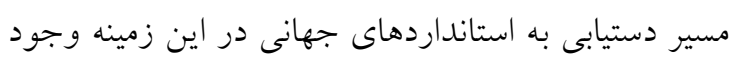

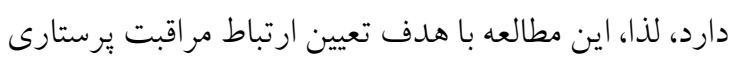

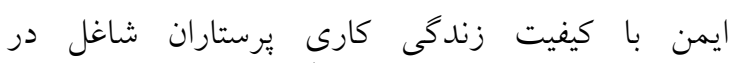
بيمارستانهاى دولتى شهر رشت انجام شد.

\section{روش بررسى}

اين بزوهش با كد اخلاق

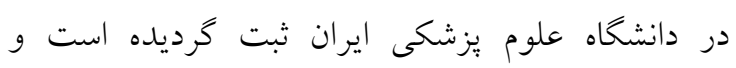
بهصورت مقطعى از نوع توصيفى - همبستخى در سال

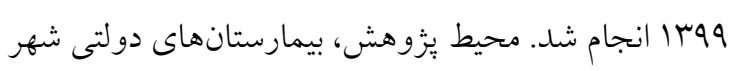

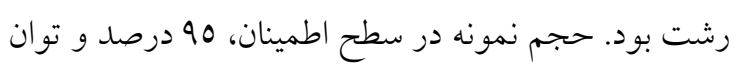

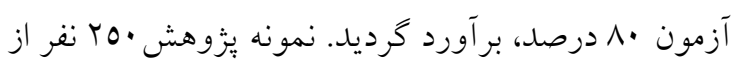

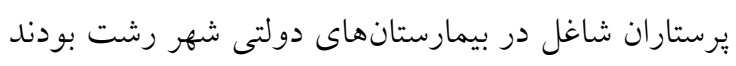

كه 70 درصد عمر مفيد انسانها در محيط كار سبرى

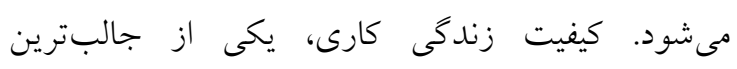

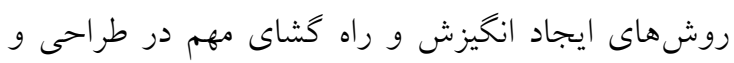
غنى سازى شغل كاركنان است؛ كه ريشه در نخرش كاركنان و مديران به مقوله انخيزش دارد (IV).

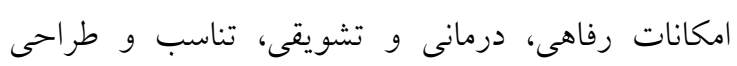

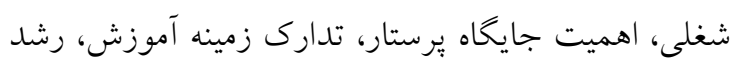

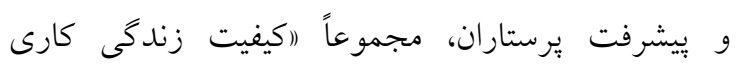

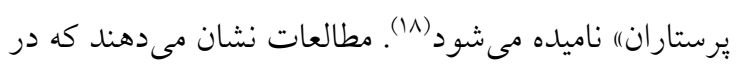

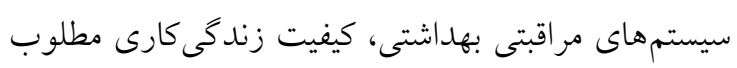

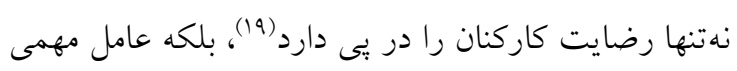

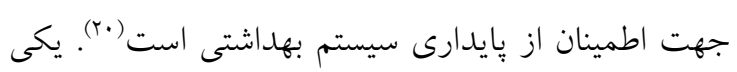

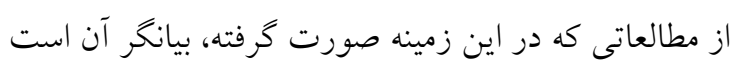
كه تنها 1/0 درصد از يرستاران از كيفيت زندكى كارى خود زئه

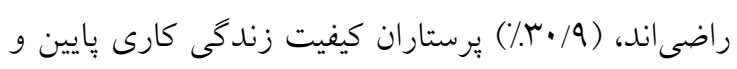

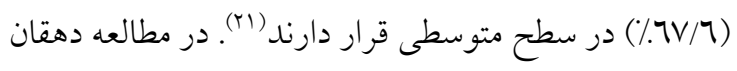

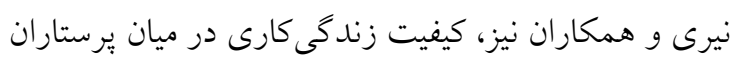

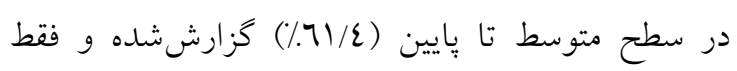

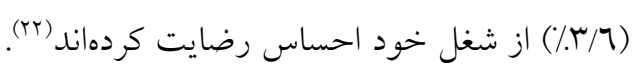

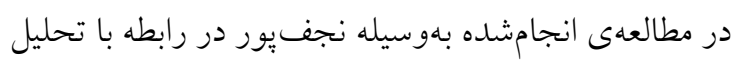

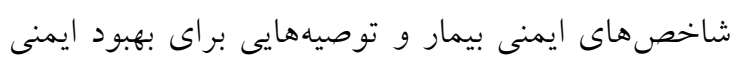

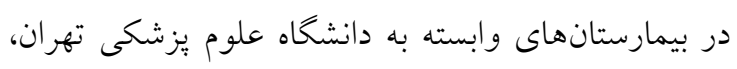
هيجيك از بيمارستانها وضعيت ايمنى مطلوبى نداشتند و

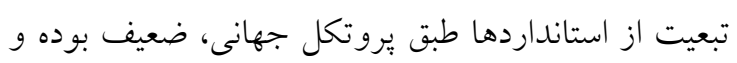

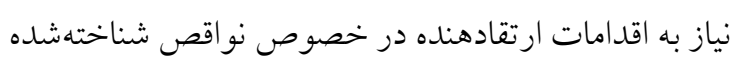

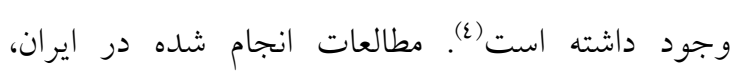
نشاندهنده نرخ سه درصدى از خطاهاى بز شكى است كه استه

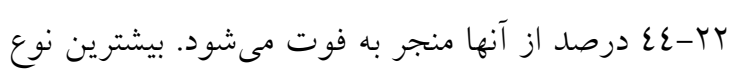
آنها نيز به ترتيب خطاهاى دارويى، اقدامات بيشخيرانه،

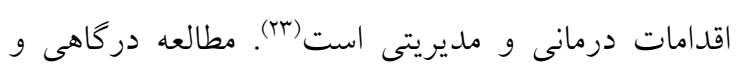

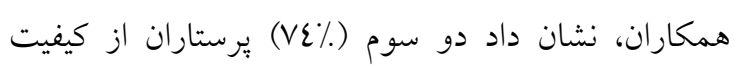

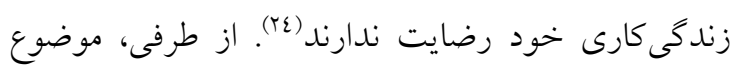

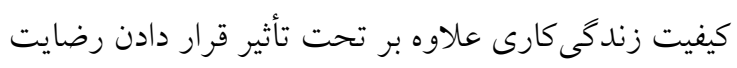

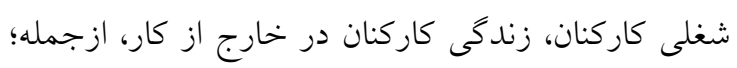


برحسب تعداديرستاران هر بخش، به كل يرستاران آن

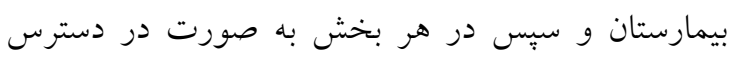
انتخاب شدند (جدول شماره ().
كه به روش نمونه كيرى طبقهاى، بر حسب تعداد برستاران

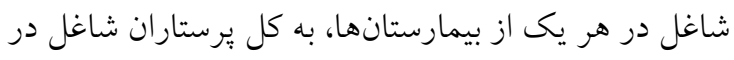

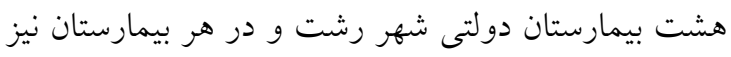

جدول شماره ا: تعداد نمونههاى يزوهش به تفكيك هر يك از مراكز

\begin{tabular}{|c|c|c|c|c|}
\hline تعداد بخش ها و سرير ستاران & تعداد نمونه انتخابشده از يرستاران & تعداد تخت فعال & تعداد برستار شاغل & 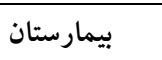 \\
\hline$\wedge$ & $(10 / r \%) \backslash 1$ & inT & 111 & الزهرا \\
\hline r & $(\% 10 / 2) 1 r$ & 91 & $\wedge \varepsilon$ & امير المؤمنين \\
\hline ir & $(\% 10 / 09) 07$ & rre & roq & 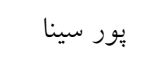 \\
\hline 9 & $(\% 10 / v) r \varepsilon$ & iv. & r17 & دكتر حشمت \\
\hline iv & $(\% 10 / 7)$ or & zor & rrqa & رازى \\
\hline 0 & $(\% / 10 / \Lambda) \mu$. & rol & 119 & شفا \\
\hline$\varepsilon$ & $(\% 10 / r) \backslash 1$ & v. & 111 & و ل الايت \\
\hline ir & $(\% 10 / \Gamma) \nvdash \Lambda$ & $10 \mathrm{~V}$ & inr & V lV ا شهريور \\
\hline
\end{tabular}

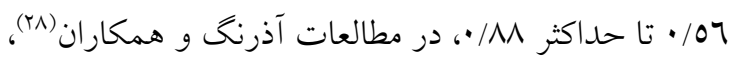

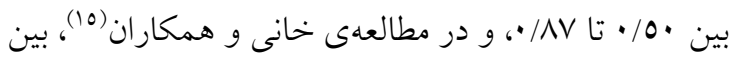

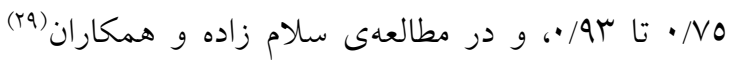

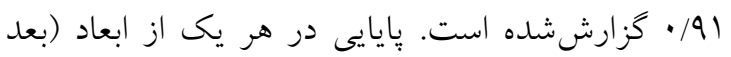

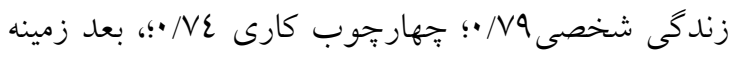

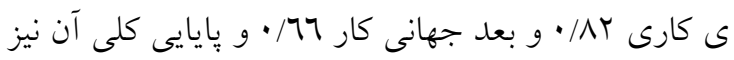

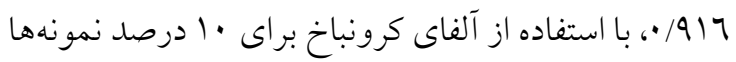
به صورت تصادفى محاسبه شد. جهت سنجش مراقبت

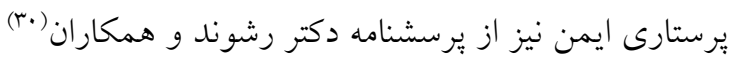

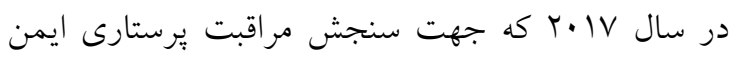

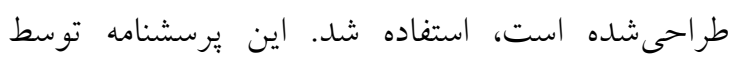

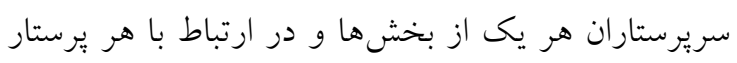

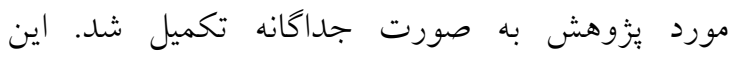

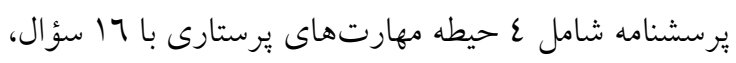

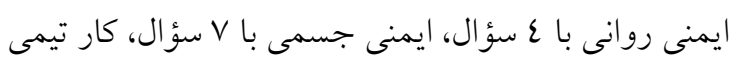

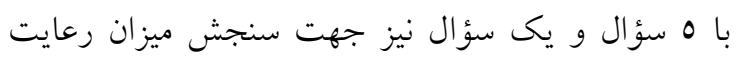
ايمنى بيمار به طور كلى است. سؤالات داراى طيف ه كانه

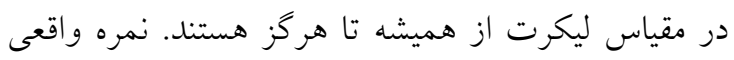

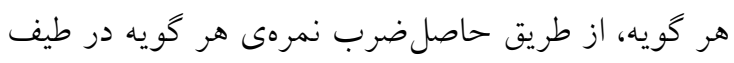

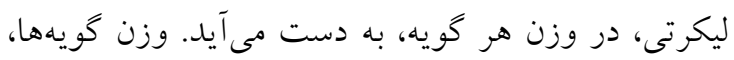

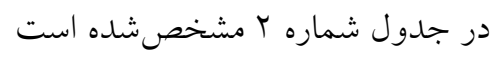

جهت جمع آورى دادهها، از يرسشنامه اطلاعات دموكرافيك شامل؛ سن، جنسيت، سطح تحصيلات، وضعيت تأهل، سابقه كار، تعداد فرزندان، وضعيت استخدامى و نوع نوبت كارى (ثابت صبح يا در كردش) نابنه

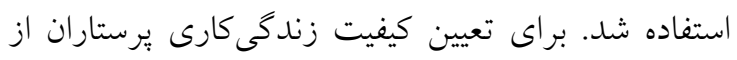
"يرسشنامه Brooks است، استفاده شد؛ اين برسشنامه توسط يُرستاران مورد

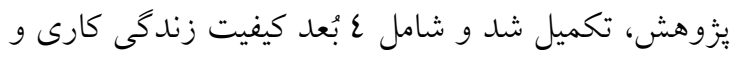

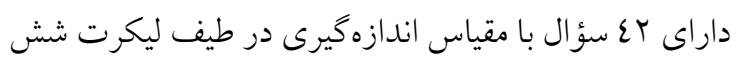

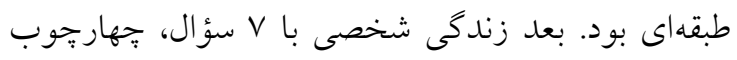

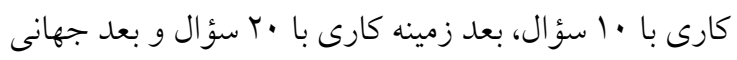

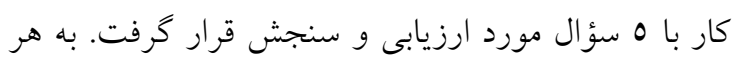

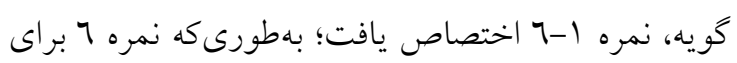

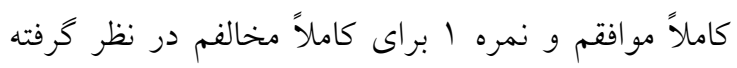

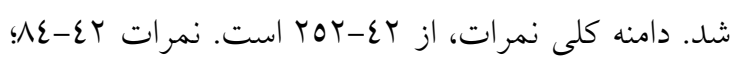

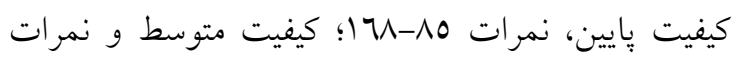
179-YOr קرسشنامهى Brooks كه در مطالعات متعددى مورد استفاده قراركرفته است، به زبان فارسى ترجمه و روايى و و پايايى آن تأييد شده است. ضريب يايايى آن با استفاده از

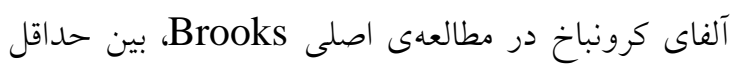


جدول شماره r: نمره واقعى هر تويه و جمع حداقل و حداكثر نمره مراقبت يرستارى ايمن

\begin{tabular}{|c|c|c|c|}
\hline حداكثر نمره & حداقل نمره & وزن كويه & 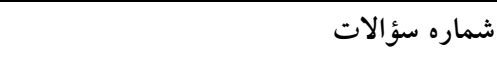 \\
\hline To & 0 & 1 & 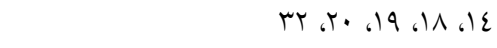 \\
\hline 10. & $r$. & r & 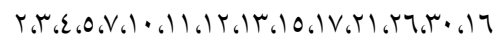 \\
\hline 10. & $r \cdot$ & r & 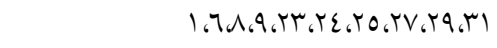 \\
\hline$\varepsilon$. & $\wedge$ & $\varepsilon$ & TY.T人 \\
\hline rao & $V r$ & & جمع حداقل و حداكثر نمره مراقبت يرستارى إ \\
\hline
\end{tabular}

درصد) متأهل بودند، ميانخين سابقه كارى آنها 1/91 با انحراف معيار ع/N سال بود (جدول شماره ب). كيفيت زندگى كارى VN/A درصد از يرستاران مورد يزوهش در

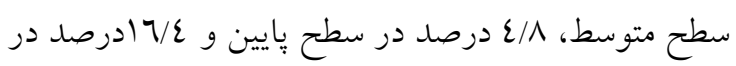
سطح بالا بود. همجنين؛ ملاحظه مى شود كه ميانخين نمره

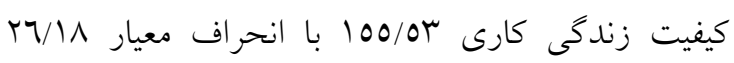
بلدست آمد. همانطوركه جدول شماره ب نشان مىدهد، مراقبت يرستارى ايمن، با جنسيت ارتباط معنىدار آمارى داشت؛ بهطورى كه ميانخين نمره ى كسبشده در زنان بهطور

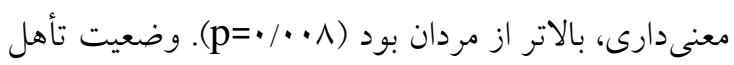

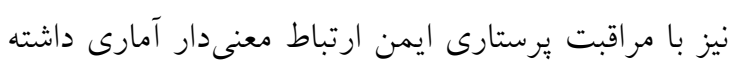
و ميانخين نمرهى كسبشده در برستاران متأهل بهطور معنى استخدامى متغير ديخرى بود كه با مراقبت يرستارى ايمن ارتباط معنى دار آمارى داشت (1 ( - p) و مقايسه دو به دو توكى نشاندهندهى آن بود كه ميانخين نمرهى كسبشده در پرستاران طرح نيروى انسانى بهطور معنى دارى كمتر از

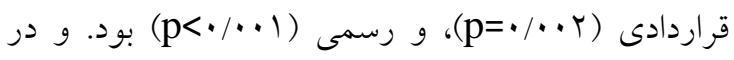
ساير سطوح اين اختلاف معنىدار نبود. در انتها ملاحظه

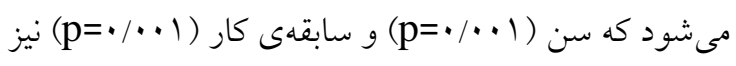
با مراقبت يرستارى ايمن همبستخى معنى دار آمارى داشتند كه اين همبستكى مثبت بود يعنى؛ با افزايش سن و سابقهى كار مراقبت يرستارى ايمن نيز افزايش مىيابد و هيجگكدام از متغيرهاى دمو گرافيك با كيفيت زندگى كارى برستاران مورد يزوهش ارتباط معنى دار آمارى نداشت.

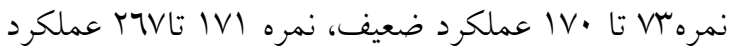

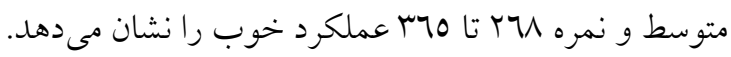

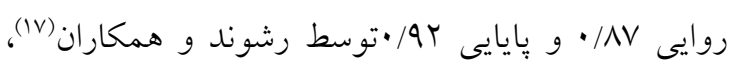

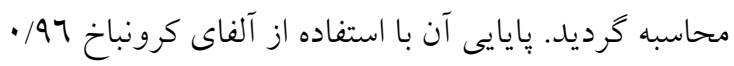
سنجيده شد. يرسشنامها توسط محقق و با مراجعه به بيمارستانهاى مورد يزوهش در اختيار ڤبرستاران و نيز

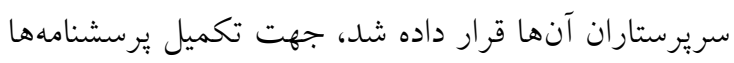
زمان •r - · ب دقيقهاى لازم است؛ با اين وجود، به نمونهاى حاضر در يزووهش و سريرستاران آنها در

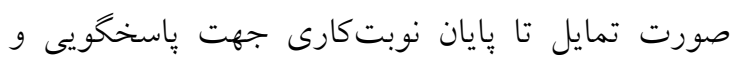
تكميل برسشنامهها فرصت داده شد. تجزيه و تحليل دادها با استفاده از نرمافزار SPSS نسخه 17 در دو بخش آمار توصيفى و آمار استنباطى صورت كرفت. در بخش آمار توصيفى، از جداول توزيع فراوانى براى متغيرهاى كيفى يُزوهش و شاخص هاى عددى كمينه، بيشينه، ميانخين و انحر اف معيار بر ای متغيرهاى كمى يزوهش استفاده شد. در بخش آمار استنباطى، از آزمونهاى ضريب همبستخى بيرسون، تى مستقل و آناليز واريانس و در صورت نياز، از مدل رگرسيون خطى جند خانه استفاده شد و سطح

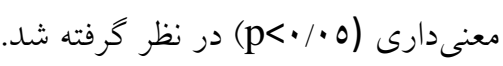

\section{يافتهها}

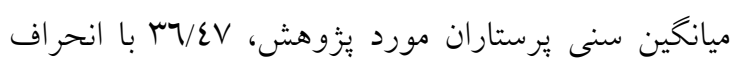
معيار V/TV سال بود. بيشتر پيرستاران مورد يزوهش (T/Y درصد) زن بودند، بيشتر (9//T درصد) تحصيلات كارشناسى داشتند. بيشتر برستاران مورد يزوهش (ع/ع) ل 
جدول شماره س: شاخصهاى عددى كيفيت زندكى كارى و مراقبت برستارى ايمن پرستاران شاغل در بيمارستان هاى دولتى شهر رشت؛ بر

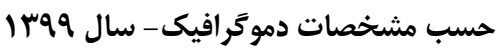

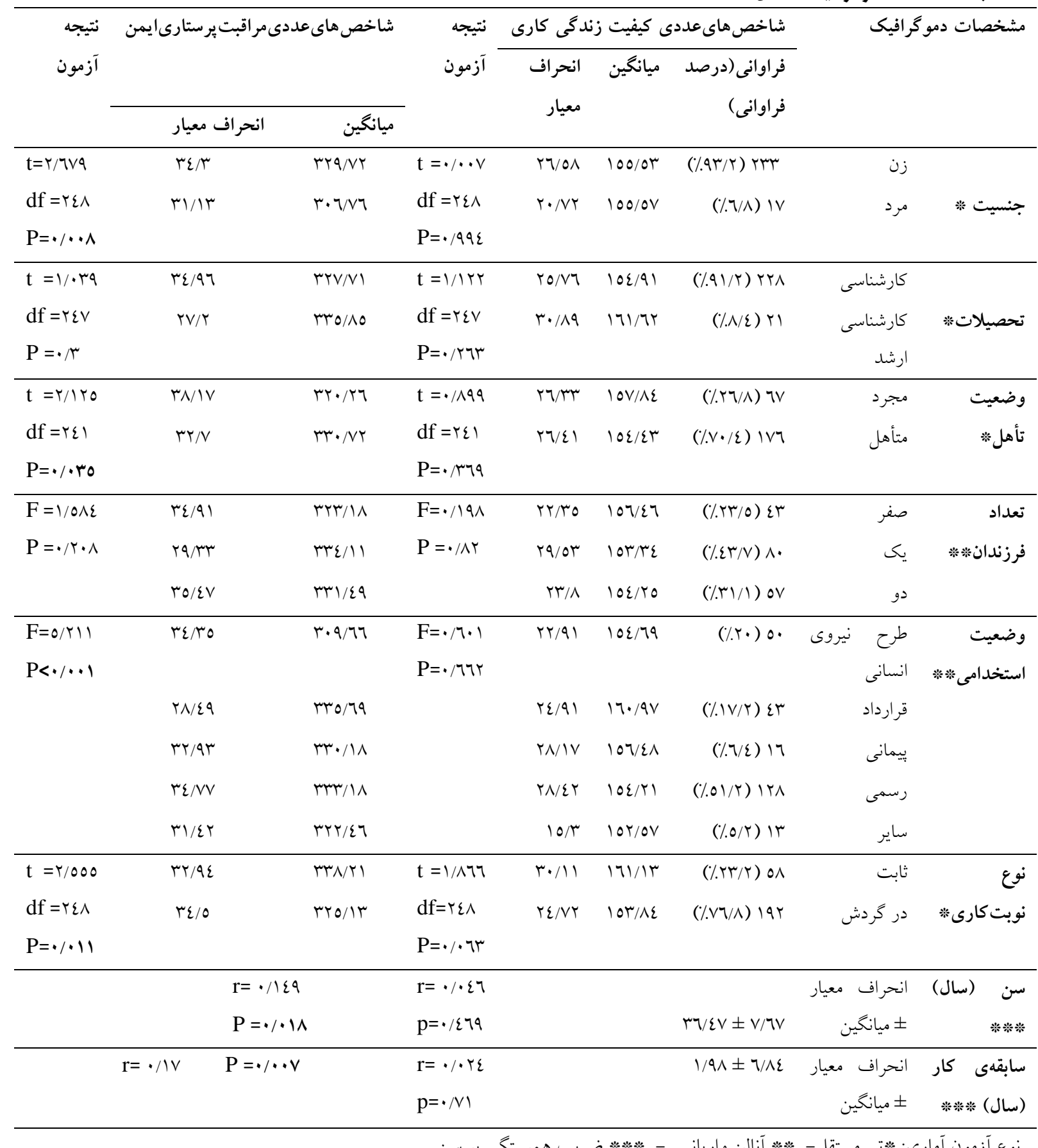

يُزوهش نشان داد، مراقبت برستارى ايمن ع/ع و درصد از يرستاران مورد يزوهش، در سطح خوب، 0/7 درصد در سطح متوسط بود و هيجگدام در سطح ضعيف نبودند.

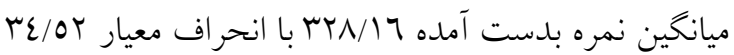

همانطور كه جدول شماره ع نشان مىدهد، كيفيت زندكى كارى در بعد زمينه كارى با ميانگين بعد جهانى كار با ميانخين r/9/9 إيايينترين ميانخين نمره را در بين ساير ابعاد داشتند. ميانخين نمره كيفيت زندكى

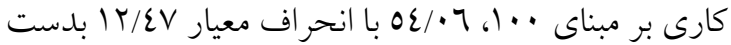
آمد كه نزديك به ميانه نمره يعنى لم است. همجنين، نتايج 


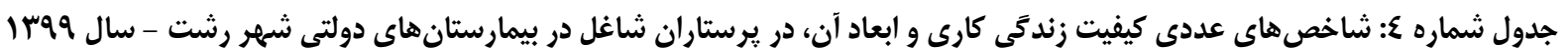

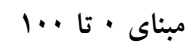

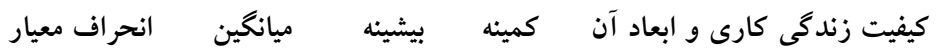

\begin{tabular}{|c|c|c|c|c|c|c|c|c|}
\hline انحراف معيار & ميانگين & بيشينه & كمينه & & & & & \\
\hline $10 / M_{1}$ & $0 . / T \wedge$ & $9 \varepsilon$ & $1 \varepsilon$ & $0 / 47$ & $T \varepsilon / \tau$ & $\varepsilon$. & Ir & زندكى شخصى (V-EY) \\
\hline $11 / 79$ & $0 \varepsilon / \cdot 9$ & 9. & 17 & $0 / 7 \varepsilon$ & $r V / \cdot \varepsilon$ & 00 & 11 & جهارجوب كارى (•7-•(1) \\
\hline $10 / V \varepsilon$ & $O \Lambda / T^{\prime}$ & $1 \cdots$ & • & $10 / \mathrm{V0}$ & $V \Lambda / V^{\top}$ & Ir. & $r \cdot$ & زمينهى كارى (•T (Y- (Y) \\
\hline$|N / T|$ & $\varepsilon 1 / 9 r$ & $1 \cdots$ & $\cdot$ & $\varepsilon / 00$ & $10 / 21$ & $r$. & 0 & 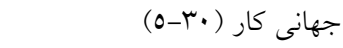 \\
\hline $\mid r / \varepsilon V$ & $0 \varepsilon / \cdot 7$ & 90 & 19 & $r \backslash / \wedge$ & $100 / 0 r$ & TEY & $\Lambda \mu$ & كيفيت زندگى كارى (EY-YOY) \\
\hline
\end{tabular}

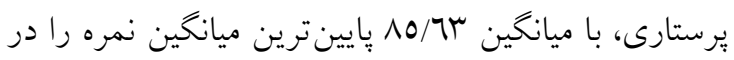
همانطور كه جدول شماره 0 نشان مىدهد، مراقبت بين ساير ابعاد داشتند. يرستارى ايمن در بعد مشاركت برستاران با ساير اعضاء تيم، با ميانخين 19/29 بالاترين و در بعد انجام مهارتهاى

جدول شماره 0: شاخصهاى عددى مراقبت يرستارى ايمن و ابعاد آن، در يرستاران شاغل در بيمارستانهاى دولتى شهر رشت- سال 1799

\begin{tabular}{|c|c|c|c|c|c|c|c|c|}
\hline \multicolumn{4}{|c|}{ مبناى · تا - 1 } & \multirow[t]{2}{*}{ انحر اف معيار } & \multirow[t]{2}{*}{ 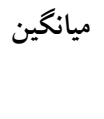 } & \multirow[t]{2}{*}{ بيشئه } & \multirow[t]{2}{*}{ كمينه } & \multirow[t]{2}{*}{ مراقبت برستارى ايمن و ابعاد آن } \\
\hline انحراف معيار & ميانخين & بيشينه & كمينه & & & & & \\
\hline $1 \pi / \varepsilon r$ & 10/7r & $1 \cdots$ & $\varepsilon$. & $|\wedge / \wedge|$ & $10 \varepsilon / 19$ & IVo & 94 & انجام مهارتهاى يرستارى (IV0-roo) \\
\hline $1 \% / 0 \varepsilon$ & $\Lambda T / 9 \varepsilon$ & $1 \cdots$ & $\varepsilon$. & Y/VI & $r Y / \mu$ & ro & ir & تأمين ايمنى جسمى (Y0-0) \\
\hline $11 / 94$ & $\wedge 9 / 1 \wedge$ & $1 \cdots$ & 0. & $9 / 0 \varepsilon$ & $91 / \pi \varepsilon$ & $1 \cdots$ & 7. & 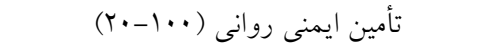 \\
\hline $1 \% / r \Lambda$ & $19 / 29$ & $1 \cdots$ & $r \varepsilon$ & $7 / 91$ & $09 / 0 \%$ & 70 & m & مشاركت يرستاران با ساير اعضاءتيم (70-1) \\
\hline $11 / \wedge r$ & $\Lambda \mathrm{V} / \Lambda$ & $1 \cdots$ & 0. & rz/or & TrN/IT & reo & r19 & مراقبت يرستارى ايمن (VY-r70) \\
\hline
\end{tabular}

همانطور كه جدول شماره 7 نشان مىدهد، مراقبت برستارى ايمن با كيفيت زندگى كارى و هيجهدام از ابعاد آنها همبستخى معنى دار آمارى نداشتند.

جدول شماره 7: همبستكى مراقبت برستارى ايمن، با كيفيت زندَّى كارى و ابعاد آنها، در يرستاران شاغل در بيمارستانهاى دولتى شهر رشت- سال وجوس

\begin{tabular}{|c|c|c|c|c|c|}
\hline \multicolumn{5}{|c|}{ كيفيت زندگى كارى و ابعاد آن } & \multirow[t]{2}{*}{ مراقبت برستارى ايمن و ابعاد آن } \\
\hline كيفيت زندگى كارى & جهانى كار & زمينه كارى & جهارجوب كارى & زندگى شخصى & \\
\hline $\mathrm{r}=\cdot / \cdot \mathrm{v} \varepsilon$ & $r=-\cdot / \cdot 1 r$ & $r=\cdot / \cdot r$ & $\mathrm{r}=\cdot / \cdot \mathrm{vr}$ & $\mathrm{r}=-\cdot / \cdot \cdot 1$ & انجام مهارت هاى برستارى \\
\hline $\mathrm{P}=\cdot / T \varepsilon r$ & $P=\cdot / \wedge \aleph \wedge$ & $\mathrm{P}=\cdot / 1 \cdot \varepsilon$ & $\mathrm{P}=\cdot /$ \%०9 & $\mathrm{P}=\cdot / 99 \mathrm{r}$ & \\
\hline$r=-\cdot / \cdot r l$ & $r=-\cdot / \cdot \wedge r$ & $r=\cdot / \cdots r$ & $\mathrm{r}=\cdot / \cdot 19$ & $\mathrm{r}=-\cdot / \cdot \varepsilon \wedge$ & تأمين ايمنى جسمى \\
\hline $\mathrm{P}=\cdot / \mathrm{V} \varepsilon\rceil$ & $\mathrm{P}=\cdot / 191$ & $\mathrm{P}=\cdot / 9 \mathrm{VV}$ & $\mathrm{P}=\cdot / \mathrm{N} 79$ & $\mathrm{P}=\cdot / \varepsilon \varepsilon \wedge$ & \\
\hline $\mathrm{r}=-\cdot \cdot \cdot \cdot \mathrm{oV}$ & $r=-\cdot / \cdot v q$ & $r=-\cdot / \cdot 17$ & $\mathrm{r}=-\cdot / \cdot \varepsilon 1$ & $r=-\cdot / 117$ & تأمين ايمنى روانى \\
\hline $\mathrm{P}=\cdot / \pi 79$ & $\mathrm{P}=\cdot / r \mid r$ & $\mathrm{P}=\cdot / \mathrm{9} \wedge$ & $\mathrm{P}=\cdot / 0 \mathrm{r}$ & $\mathrm{P}=\cdot / \cdot 7 \mathrm{~V}$ & \\
\hline$r=-\cdot / \cdots 0$ & $r=-\cdot / \cdot o r$ & $r=\cdot / \cdot 7$ & $r=. / .09$ & $r=-\cdot / \cdot 0 \varepsilon$ & مشاركت تيرستاران با ساير اعضاء تيم \\
\hline $\mathrm{P}=\cdot / 94 q$ & $\mathrm{P}=\cdot / \varepsilon \cdot r$ & $\mathrm{P}=\cdot / 9 r q$ & $\mathrm{P}=\cdot$ ror & $\mathrm{P}=\cdot / 490$ & \\
\hline$r=\cdot / \cdot r r$ & $r=-\cdot / \cdot\{7$ & $r=\cdot / \cdot o r$ & $\mathrm{r}=\cdot / \cdot\{1$ & $\mathrm{r}=-\cdot / \cdot \varepsilon \mathrm{V}$ & مراقبت برستارى ايمن \\
\hline $\mathrm{P}=\cdot / V Y \Lambda$ & $\mathrm{P}=\cdot / 279$ & $\mathrm{P}=\cdot / \varepsilon \cdot 0$ & $\mathrm{P}=\cdot / 019$ & $\mathrm{P}=\cdot / \varepsilon\rceil$ & \\
\hline
\end{tabular}


كيفيت زندكى كارى برستاران است و رابطهى منفى

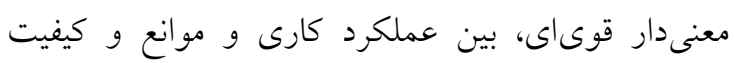

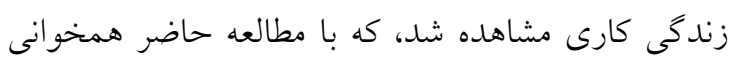

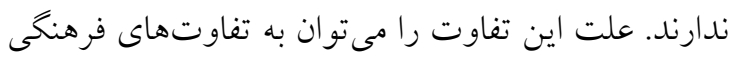

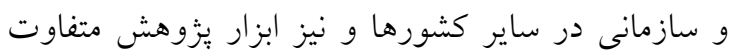

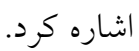
كيفيت زندكى كارى بيشتر برستاران مورديزوهش در سطح

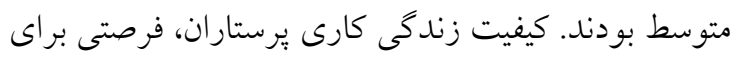
آنها فراهم مى آورد تا مشاركت آنان با سازمان، معنى دار

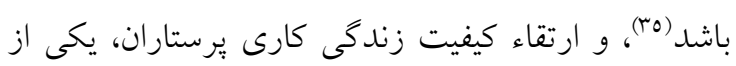

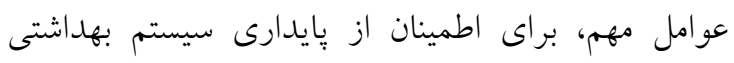

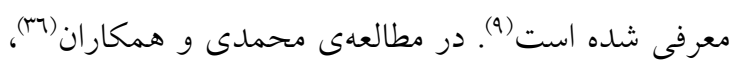

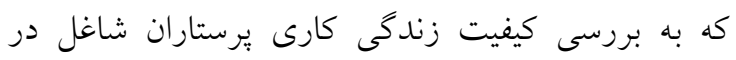

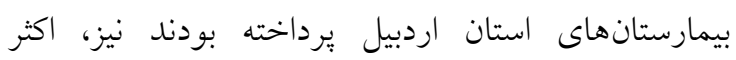

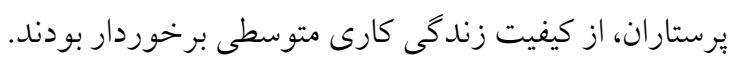

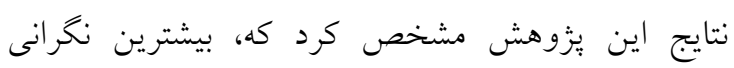
برستاران كه كيفيت زندگى كارى آنان را تحت تأثير قرار مىدهد؛ بُعد جهانى كار است، كه شامل "تصوير صحيح

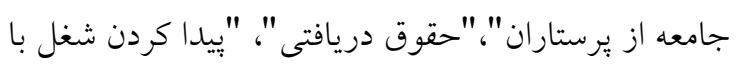

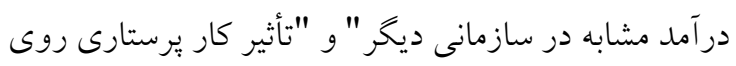

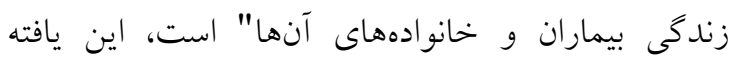

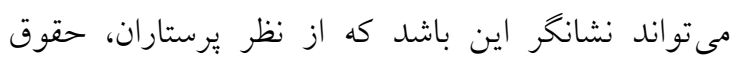

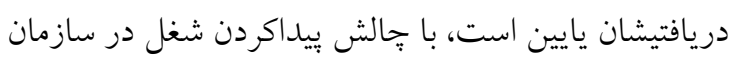
ديخر روبرو هستند، جامعه بدرستى بيى به نقش و جايخاه برستار نبرده است ولى با اين وجود كار پِرستارى تأثير

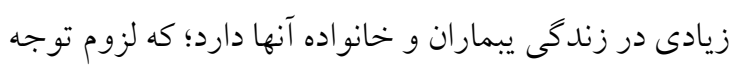

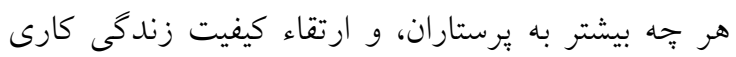

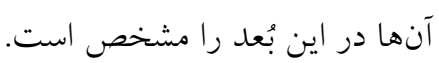

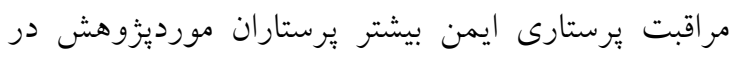

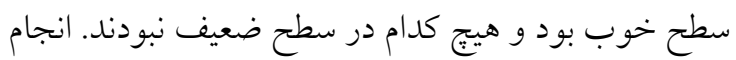
كار ايمن براى حفظ ايمنى بيمار، هستهى مركزى بـ بهرد

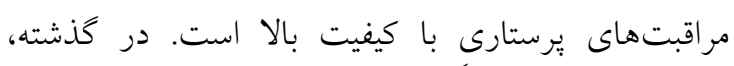

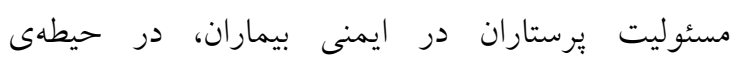

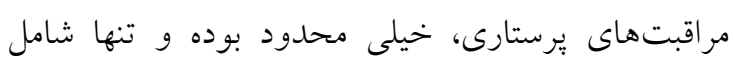

\section{بحث و نتيجه كيرى}

مراقبت برستارى ايمن، با كيفيت زندكى كارى و و هيجيجكدام

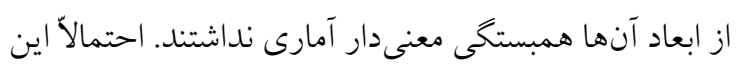

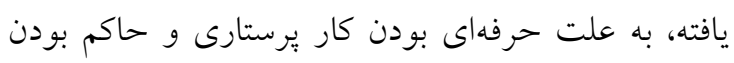

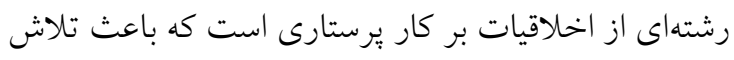

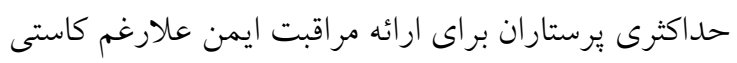
هاى موجود در كيفيت زندكى كاريشان است. مطالعه مشابه

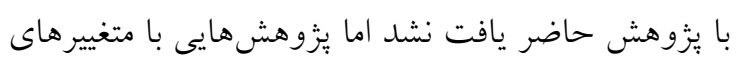
مشابه نتايجى همسو و غيرهمسو با بزّوهش كنونى داشتند.

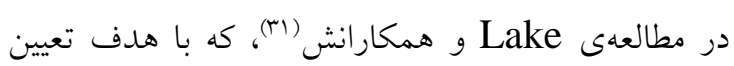

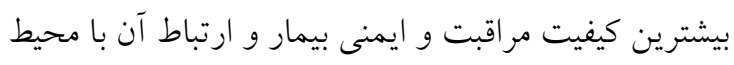
كارى در NICU انجام شد، مشخص شد كه بهبود عوامل

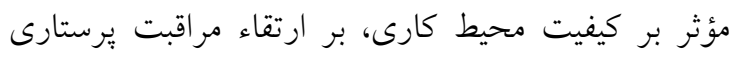

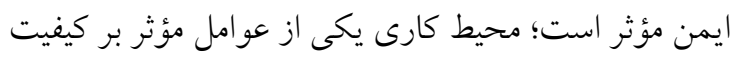
زندكى كارى است ولى ساير عوامل احتمالاً بتوانند از تأثير

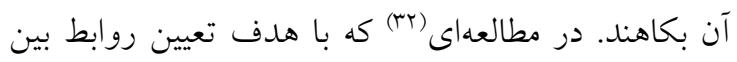

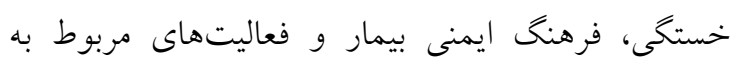
مراقبت ايمن در برستاران بيمارستان، به شناسايى و توضيح

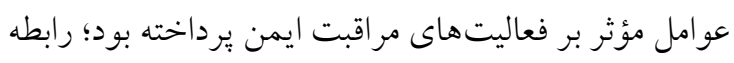

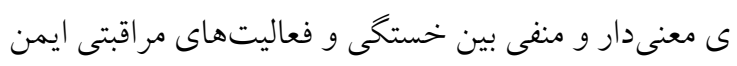

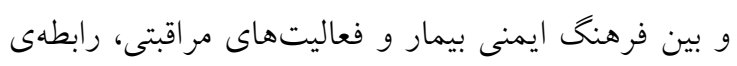

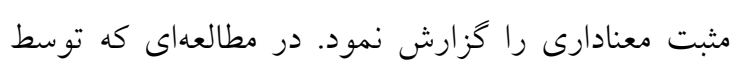
Sarafis موقعيت استرسزا، با رفتار مراقبتى بدتر براى بيمار همراه

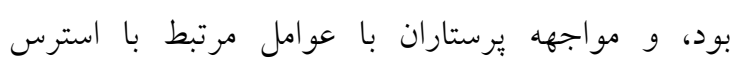

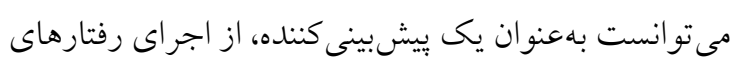
مراقبتى آنان محسوب شود و بر كيفيت زندگى آنان تأثير

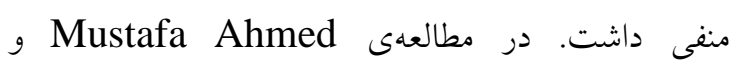
همكاران (ع)، كه باهدف شناسايى موانع عملكرد برستاران و كيفيت زندكى كارى آنها در بيمارستانهاى آموزشى هـاني

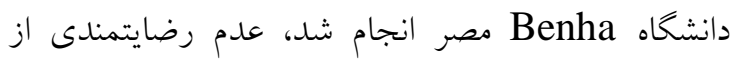
نوبت كارى، ازدياد نوبتهاى در كردش، كاهش انخيزهى كارى، حقوق، مزايا، نيروى كار و استخدام يرستار، همجنين إنين

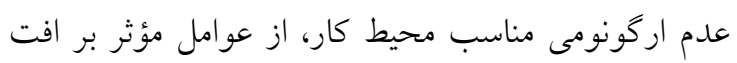


كندههاى خوبى براى تعيين كيفيت زندكى كارى برستاران

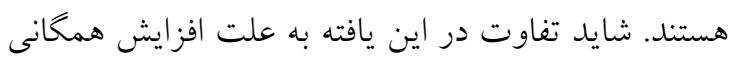

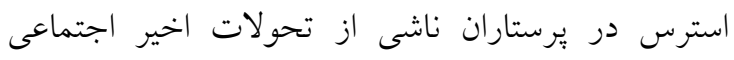

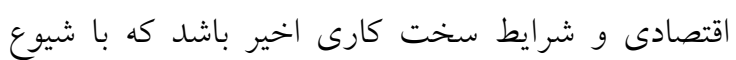
بيمارى همه كيرى تنفسى كرونا ويروس (COVID-19)

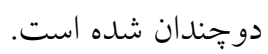
مراقبت برستارى ايمن با جنسيت، ارتباط معنىدار داشت.

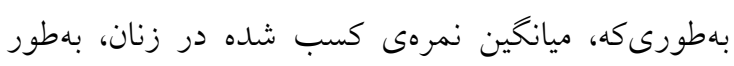

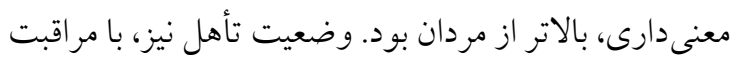

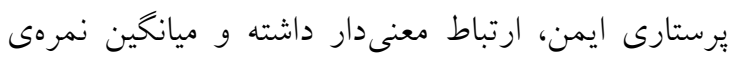
كسب شده در بِرستاران متأهل، بهطور معنى دارى بالاتر از از

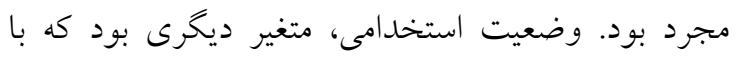

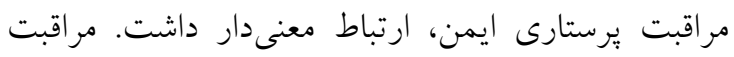

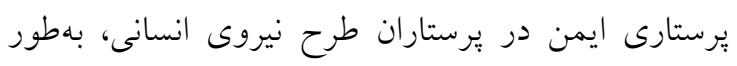

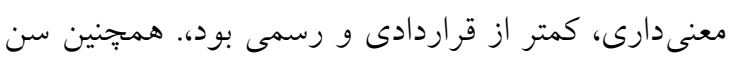

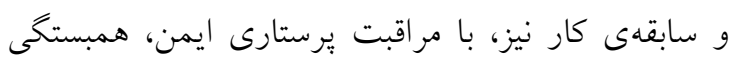

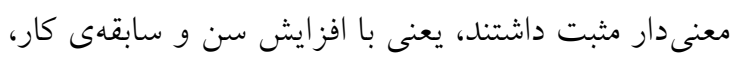

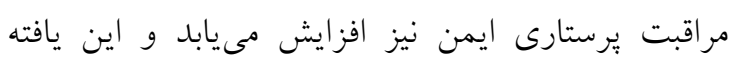

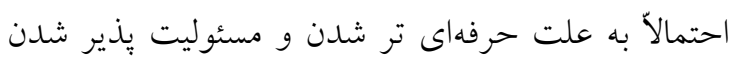
يرستاران با افزايش سن و سابقه كارى است. يافته هاى

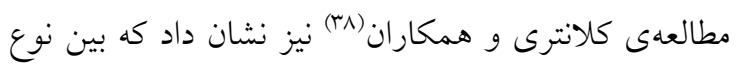

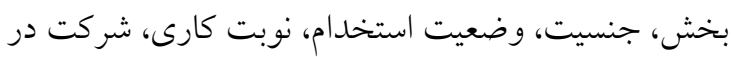

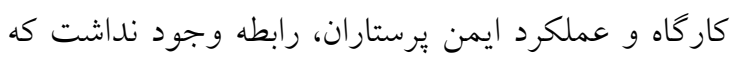
اين يافتهها، با مطالعه حاضر متفاوت است.

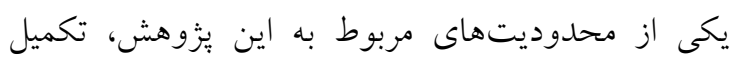
يرسشنامهى مر اقبت برستارى ايمن، در بخشهاى مختلف،

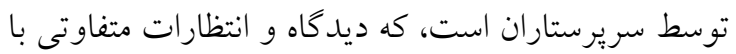

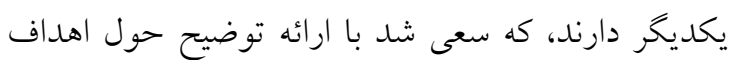

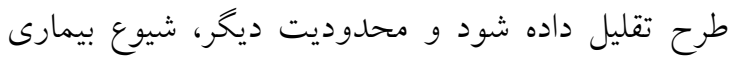

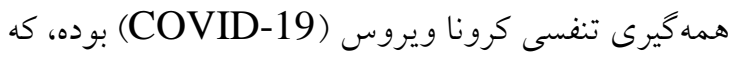

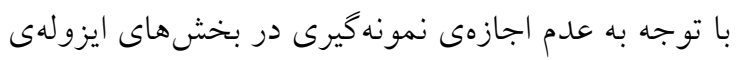

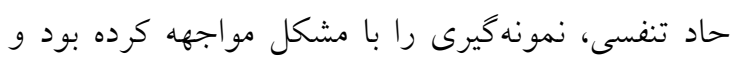

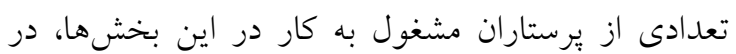

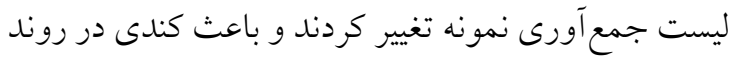

بيشخيرى از اشتباهات دارويى و بيشخيرى از افتادن بيمار

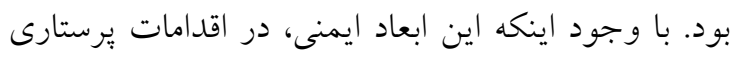

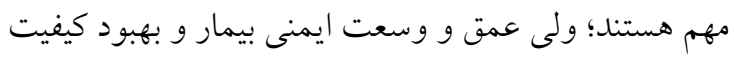

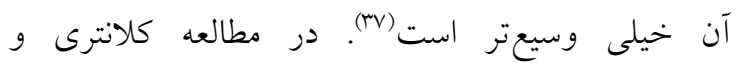

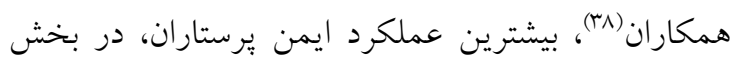

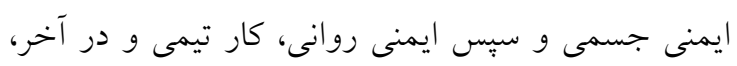

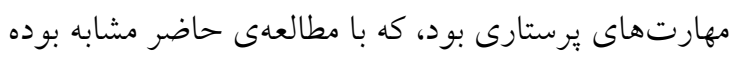

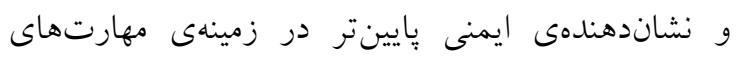

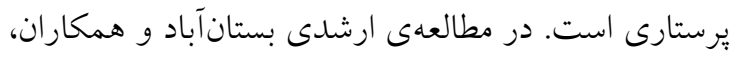

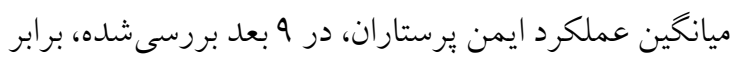

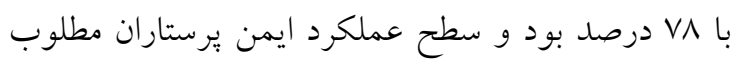

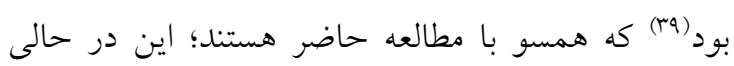

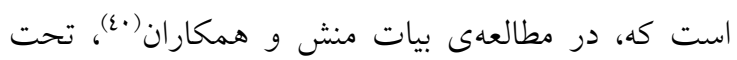
عنوان (بررسى ميزان رعايت ايمنى بيمار توسط يرستار دهان

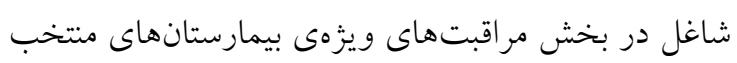

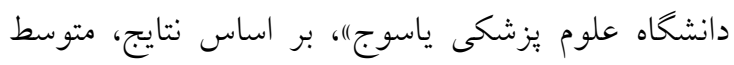

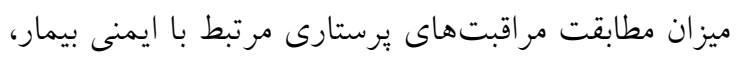

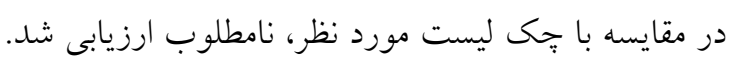

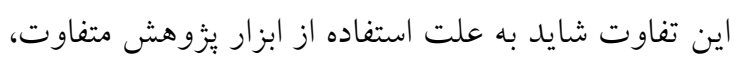
محيط و مؤلفه هاى مورد مطالعه باشد.

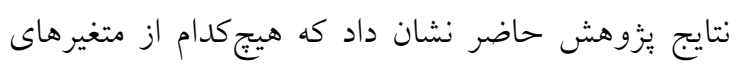

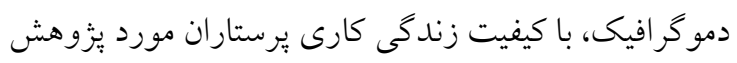
ارتباط نداشت. نتايج مطالعه محمدى و همكاران (بان) نيز

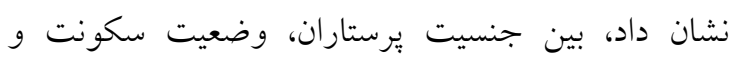
مدرى تحصيلى آنها، با كيفيت زندكى كارى و نيز بين بندين

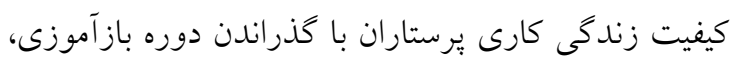

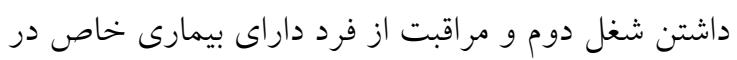
خانواده، ارتباط وجود نداشت؛ كه با مطالعهى حاضر

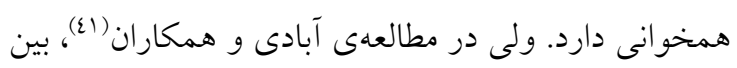

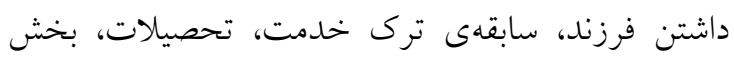
محل خدمت، ساعات اضافه كار برستاران با برخى ابعاد متغير كيفيت زندكى كارى، ارتباط معنى دار مشاهده كرديد.

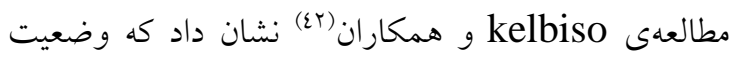
تحصيلى، درآمد ماهانه، واحد كارى و محيط كار، ييش بـ بينى 
مراقبت يرستارى ايمن، در سطح خوبى بود؛ ولى با توجه

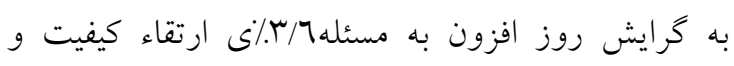
رقابت سازمانهاى ارائهدهندهى خدمات سلامت براى جذب مشترى، نياز به ارتقاء روزافزون آن است و برستاران مورد يزوهش در بعد مهارت بالينى مراقبت برستارى ايمن

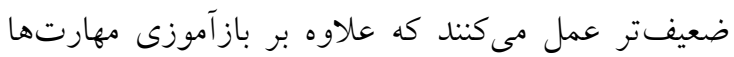
نيازمند يايش بيشتر در اين زمينه نيز مىباشد. با توجه به له

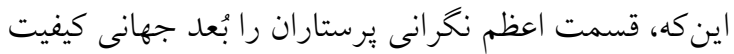

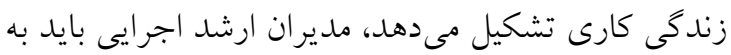
مقولهى حقوق و دستمزد، امنيت شغلى و ايجاد تصوير صحيح از يرستارى در سطح جامعه، توجه ويزه داشته باشند، و جهت ارتقاء اين موارد، با حداكثر توان خود تلاش

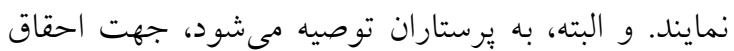
جايگاه خود در جامعه، و نيز ارتقاء امنيت شغلى خود، به تقويت روحيهى مطالبه كرى توجه داشته باشند.

تعارض منافع: هيج گونه تعارض منافع توسط نويسندگان

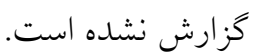

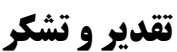

بدين وسيله از همكارى و مشاركت تمامى پِرستاران بيمارستانهاى دولتى شهر رشت كه در تكميل يرسشنامه همكارى نمودهاند تشكر و قدردانى به عمل مي آيد.
نمونه كيرى شد كه با مر اجعه مستمر و بييخيرى روند، كاهش يافت با توجه به اينكه جامعلى آمارى مربوط به بيمارستان

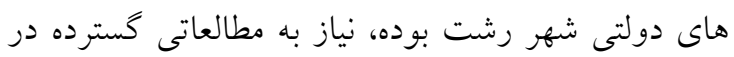

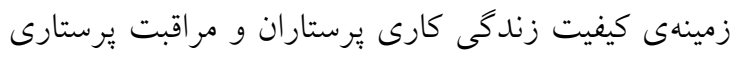

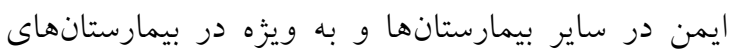
خصوصى براى بالا بردن صحت يافتههاى يزوهش است.

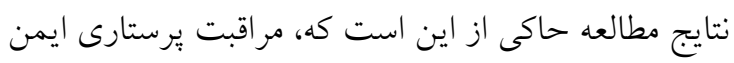
بيشتر يرستاران مورد يزوهش، در سطح خوب بود و هيج كدام در سطح ضعيف نبودند. كيفيت زندكى كارى بيشتر

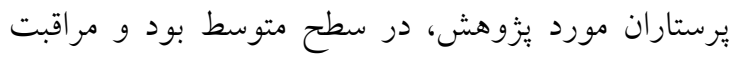

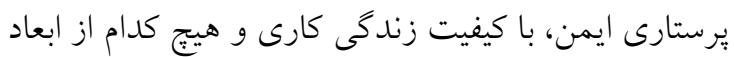

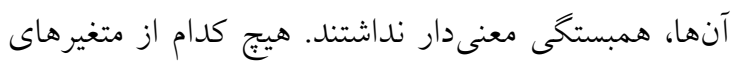

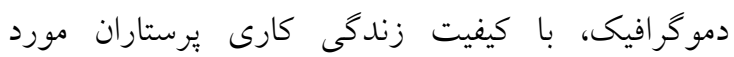
يُزوهش، ارتباط معنى دار نداشت و مراقبت يرستارى ايمن،

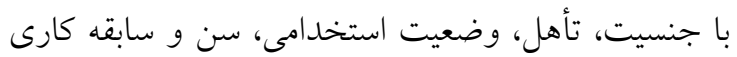

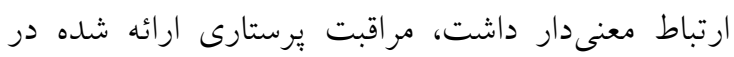

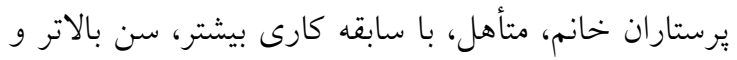

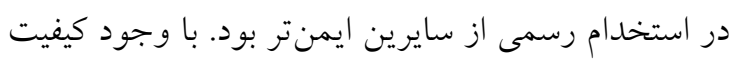

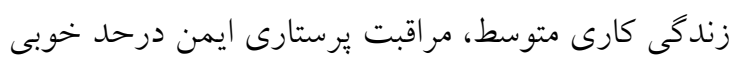

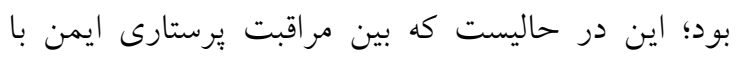

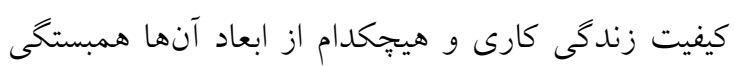

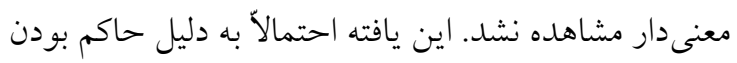

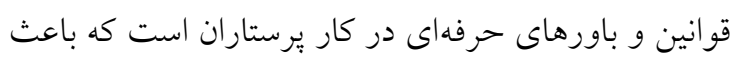

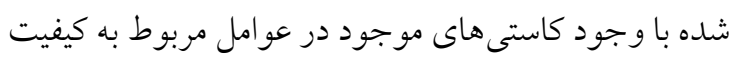
زندگى كارى، مراقبت ارائه شده همجِنان كاملاً ايمن باشد.

\section{References}

1. Hasani .A ,Mobaraki. H, heyrani.A , Bayat.M, Mafi Moradi.SH , Hadi.M. The new human resources management in the health .Tehran, Parsenegar: 2013;(1). [Persian]

2. Bassuni EM, Bayoumi MM. Improvement critical care patient safety: using nursing staff development strategies, at Saudi Arabia. Glob J Health Sci. 2015;7(2):335.

3. Brooten D, Youngblut JM, Kutcher J, Bobo C. Quality and the nursing workforce: APNs, patient outcomes and health care costs. Nursing outlook. 2004;52(1):45-52.

4. Najafpour Z, Mahmoodi M, Pourreaza A. Analysis of patient safety indicators in hospitals affiliated with Tehran University of Medical Sciences: recommendations for improving patient safety. Journal of Hospital. 2015;13(4):53-61. [Persian]

5. Tourani S, Khodayari Zarnaq R, Arabloo J, Esmaili A, Taghizadeh S, Khosravizadeh O. A survey on patient safety using the farsi version of the safety attitudes questionnaire in Iran. Journal of Payavard Salamat. 2016;10(1):82-92. [Persian] 
6. Shamsadini Lori A, Osta A, Atashbahar O, Ramazani S, PourAhmadi M, Ahmadi Kashkoli S. Patient safety culture from the viewpoint of nurses of teaching hospitals affiliated with Shahid Beheshti University of Medical Sciences. Journal of Health Based Research. 2016;2(1):81-92. [Persian]

7. Mosadeghrad A, Shakibaei E. Hospital accreditation implementation prerequisites. Journal of Hospital. 2017;16(3):43-56. [Persian]

8. Safety WP, World Health Organization. Conceptual framework for the international classification for patient safety version 1.1: final technical report January 2009. World Health Organization; 2010, $1-154$.

9. World Health Organization. 10 facts on Patient Safety. (Accessed July 1, 2018, at http://www.who.int/features/factfiles/patient_safety/en/).

10. Stang A, Thomson D, Hartling L, Shulhan J, Nuspl M, Ali S. Safe care for pediatric patients: a scoping review across multiple health care settings. Clinical pediatrics. 2018;57(1):62-75.

11. Makary MA, Daniel M. Medical error — the third leading cause of death in the US. Bmj. 2016 3;353.

12. Reason JT, Carthey J, de Leval MR. Diagnosing "vulnerable system syndrome": an essential prerequisite to effective risk management. BMJ Quality \& Safety. 2001;10(suppl 2):ii21-5.

13. Hughes R, editor. Patient safety and quality: An evidence-based handbook for nurses. 2008; 1-30.

14. Purreza.A, Ghodarzi. GH, Azadi.H. productivity and quality of work life, Ayene weekly press. 2006:569.

15. Khani A, Jaafarpour M. Quality of nursing work life. Journal of Clinical and Diagnostic Research. 2008;2(6):1169-74. [Persian]

16. Marquis BL, Hustone CJ. Leadership roles and management functions in nursig. 2017. $9^{\text {th }}$ ed:606.

17. Gholami.AR. Factors Affecting the Quality of Work Life in an Organization. Bimonthly of Police Human Development. 2009;6( 24):80-100.

18. Bazaz Jazayeri A, Pardakhtchi M. Creating model of assessing quality of life of staffs in organization. Management Science Journal. 2007;5:123-51. [Persian]

19. Cimete G, Gencalp NS, Keskin G. Quality of life and job satisfaction of nurses. J Nurs Care Qual. 2003;18(2):151-8.

20. -Saber S, Borhani F, Navidian A, Ramezani T, Rezvan Amin M, Kayanids T. Its quality of nursing work life and productivity Kerman University of Medical Sciences in 2012. The iranian Journal of Bioethics. 2012;3(9):144-66. [Persian]

21. Habibzadeh H, Ghorbanzadeh K, Khalkhali H, Mohammadpor Y. Investigation of the relationship between quality of work life and clinical competence in nurses. Uromia Nurs Mid Faculty J. 2012;10:332-9. [Persian]

22. Dehghan Nayeri N, Salehi T, Asadinoghaby AA. Quality of work life and productivity of clinical nurses and their relationship with each other. Nurse Res. 2009;8(9):27-37. [Persian]

23. Shamsaii M, Faraji O, Ramazani A, Hedaiati P. The viewpoints of Zabol's General Practitioners about medical errors in 2010. Hospital. 2012;10(439):31-6. [Persian]

24. Dargahi H, Gharib MI, Goodarzi M. Quality of work life in nursing employees of Tehran University of Medical Sciences hospitals. Journal of hayat. 2007;13(2):13-21. [Persian]

25. Khadivi A, Aliee H. Study of the quality of working life of the employees of Islamic Azad University of Tabriz Branch. JMS. 2007;1(2):150-72. [Persian]

26. Mohamadi J, Ghazanfari F, Azizi A. Relationship between moral intelligence and nurses' quality of work life. Iran Journal of Nursing. 2014;27(90):54-64. [Persian]

27. Brooks BA, Anderson MA. Defining quality of nursing work life. Nursing Economics. 20051;23(6):319-26.

28. Azarrang SH, Yaghmaei F, Shiri M. Correlation dimensions of quality of work life of nurses and demographic characteristics. Iranian Journal of Nursing Research. 2013;7(27):18-24. [Persian]

29. Salam Zadeh Y, Mansoori H, Farid D. Study of the relation between quality of work life and productivity of human resources in health care institutes-a case study among nurses in Shahid Sadughi Hospital in Yazd. Nursing And Midwifery Journal. 2008;6(2):60-70. [Persian]

30. Rashvand F, Salsali M, Ebadi A, Vaismoradi M, Jordan S, Griffiths P. Iranian nurses perspectives on assessment of safe care: an exploratory study. Journal of nursing management. 2016;24(3):41726. [Persian] 
31. Lake ET, Hallowell SG, Kutney-Lee A, Hatfield LA, Del Guidice M, Boxer B, Ellis LN, Verica L, Aiken LH. Higher quality of care and patient safety associated with better NICU work environments. J Nurs Care Qual. 2016;31(1):24.

32. Yang YK. Factors influencing safety care activities of hospital nurses. J Korean Acad Fundamen Nurs. 2019;26(3):188-96.

33. Sarafis P, Rousaki E, Tsounis A, Malliarou M, Lahana L, Bamidis P, Niakas D, Papastavrou E. The impact of occupational stress on nurses' caring behaviors and their health related quality of life. BMC nursing. $2016 \mathrm{c} ; 15(1): 1-9$.

34. Ahmed WA, Soliman ES, Shazly MM. Staff Nurses' Performance Obstacles and Quality of Work Life at Benha University Hospital. Journal of Nursing and Health Science (IOSR-JNHS) 2018;7(2): 65-71.

35. Daubermann DC, Tonete VL. Quality of work life of nurses in primary health care. Acta Paul Enferm. 2012;25(2):277-83.

36. Mohammadi M, Mozaffari N, Dadkhah B, Etebari Asl F, Etebari Asl Z. Study of work-related quality of life of nurses in Ardabil Province Hospitals. J Health Care. 2017 0;19(3):108-6. [Persian]

37. Tourangeau AE, Cranley LA, Jeffs L. Impact of nursing on hospital patient mortality: a focused review and related policy implications. BMJ Quality \& Safety. 2006;15(1):4-8.

38. SA S, SAH P. Evaluation of nurses 'performance from nurses' viewpoints on providing safe care to patients in AjA hospitals in 2018. Military Caring Sciences Journal. 2019;5(3):173-81. [Persian]

39. Arshadi Bostanabad. M, Jebreili.M, kargari Rezapour. M. Assessment of Nursing Safe Performance in Neonatal Intensive Care Units of Tabriz. Journal of Pediatric Nursing. 2015;1(2):49-60. [Persian]

40. Bayatmanesh H, Zagheri Tafreshi M, Manoochehri H, Akbarzadeh Baghban A. Patient Safety Observation by Nurses Working in the Intensive Care Units of Selected Hospitals Affiliated to Yasuj University of Medical Sciences. ISMJ. 2019;21(6):493-506.

41. Abadi F, Abadi F. Survey Factors Affecting of Quality of Work Life in the Clinical Nurses. Nursing And Midwifery Journal. 2019;16(11):832-40. [Persian]

42. Kelbiso L, Belay A, Woldie M. Determinants of quality of work life among nurses working in Hawassa town public health facilities, South Ethiopia: a cross-sectional study. Nursing Research and Practice. 2017;2017. 